\title{
Penelusuran Ragam Jenis Bambu di Kota Langsa, Aceh
}

\author{
Muhammad Azli Ritonga1, Siti Nurchalidah', Karmiati', Zidni Ilman Navia1, Adi Bejo Suwardi ${ }^{2}$ \\ 1Program Studi Biologi, Fakultas Teknik, Universitas Samudra \\ 2Program Studi Pendidikan Biologi, Fakultas Keguruan dan Ilmu Pendidikan, Universitas Samudra \\ E-mail: muhammadazli405@gmail.com, sitinurchalidah14@gmail.com,kar.miati091098@gmail.com \\ navia1529@gmail.com, adi.mipa@gmail.com
}

\begin{abstract}
Langsa City has a wealth of plant species that need to be studied, especially bamboo plants. This study aims to explore the types of bamboo found in Langsa City. The study was conducted from April to July 2019 using the exploration method. The method of sample collection by purposive sampling. The results showed that in Langsa City there were found 4 genera bamboo namely Bambusa, Gigantochloa, Schizostachyum, and Thyrsostachys which consisted of 6 species of bamboo namely Bambusa multiplex (Lour.) Raeusch. Ex Schhult., Bambusa vulgaris Schrad. Ex Wendl., Gigantochloa apus (J.A. \& J.H.Schult.) Kurz, Gigantochloa atter (Hassk.) Kurz, Schizostachyum brachycladum (Kurz) Kurz, and Thyrsostachys siamensis Gamble. The most widespread bamboo distribution in Langsa was found in Langsa Lama and Langsa Baro amounted to 5 species.
\end{abstract}

Keywords: bamboo, inventory, diversity, Langsa, Aceh

\section{Abstrak}

Kota Langsa memiliki kekayaan jenis tanaman yang perlu dikaji, khususnya tanaman bambu. Penelitian ini bertujuan untuk menelusuri jenis-jenis bambu yang terdapat di Kota Langsa. Penelitian telah dilakukan pada bulan April hingga Juli 2019 dengan menggunakan metode eksplorasi. Metode pengumpulan sampel dilakukan dengan purposive sampling. Hasil penelitian menunjukkan bahwa di Kota Langsa ditemukan sebanyak 4 marga bambu yaitu Bambusa, Gigantochloa, Schizostachyum, dan Thyrsostachys yang terdiri atas 6 jenis bambu yaitu Bambusa multiplex (Lour.) Raeusch. Ex Schhult., Bambusa vulgaris Schrad. Ex Wendl., Gigantochloa apus (J.A. \& J.H.Schult.) Kurz, Gigantochloa atter (Hassk.) Kurz, Schizostachyum brachycladum (Kurz) Kurz, dan Thyrsostachys siamensis Gamble. Persebaran bambu di Kota Langsa paling banyak dijumpai di Kec. Langsa Lama dan Langsa Baro berjumlah 5 jenis.

Kata kunci: bambu, inventarisasi, keanekaragaman, Langsa, Aceh

\section{Pendahuluan}

Keanekaragaman jenis bambu di dunia cukup tinggi, tercatat diketahui ada 1250 jenis bambu yang berasal dari 75 marga (Sulistiono et. al., 2016). Hasil penelusuran Widjaja (2001), di Indonesia tumbuh berbagai macam bambu yang sekitar 143 jenis telah diketahui sifat dan jenisnya. Bambu merupakan salah satu hasil hutan non kayu yang memiliki peran penting dalam memenuhi kebutuhan masyarakat (Ridwansyah et. al. 2015). Hingga saat ini bambu telah dimanfaatkan dalam berbagai aspek kehidupan. Manfaat bambu ditinjau dari nilai ekonomi bambu digunakan sebagai bahan kerajinan sebagai mata pencaharian (Putro et. al. 2014). Bambu memiliki sistem perakaran yang banyak dan kuat, serta mempunyai fungsi dalam mencegah erosi, tanah longsor, dan banjir yang mana ini manfaat bambu ditinjau dari segi ekologis (Hadjar et. al., 2017). Menurut Zulkarnaen dan Wardani, (2015) bahwa beberapa jenis bambu di alam mulai terancam keberadaannya dikarenakan over eksploitasi, perubahan fungsi lahan maupun kebakaran lahan terutama jenis bambu yang bernilai ekonomi. Upaya konservasi bambu juga telah dilakukan seperti di Kebun Raya Baturraden Banyumas Jawa Tengah (Sukma dan Lianah, 2019).

Provinsi Aceh diketahui memiliki keanekaragaman hayati yang tinggi, hal ini karena adanya kawasan Taman Nasional Gunung Leuser (TNGL). Berbagai hasil penelitian di Aceh tentang keanekaragaman hayati telah didata. Hasil penelitian tersebut menunjukkan bahwa keanekaragaman hayati sangat tinggi, seperti tumbuhan buah yang dapat dimakan di Provinsi Aceh sangat beragam dan berpotensi sebagai sumber pangan fungsional (Rahmawati \& Hayati, 2013, Navia et. al., 2019, Navia et. al., 2020, Saputri \& Navia, 2017, Suwardi et. al. 2019b, Suwardi et. al. 2020a). Jenis buah yang banyak dibudidayakan oleh masyarakat khususnya mangga dan durian (Navia et. al., 2017, Suwardi et. al., 2019a, Suwardi 
et. al. 2020b), diketahui jenis durian di Indonesia terdapat 29 jenis baik liar maupun budidaya (Navia \& Chikmawati, 2015). Disamping itu juga terdapat tumbuhan palem dan herba yang berpotensi sebagai obat herbal (Saputri et. al., 2018, Suwardi et. al., 2018,) dan ragam jenis jamur makroskopis yang tersebar di Kota Langsa (Afriani et. al., 2019, Garuda et. al. 2019). Langsa salah satu wilayah yang terletak di pesisir Aceh bagian timur. Potensi yang dimiliki Kota Langsa di antaranya yaitu memiliki kawasan hutan mangrove yang luas dan berfungsi dalam menyimpan cadangan karbon (Suwardi et. al., 2017), keragaman fitoplankton di kawasan perairannya (Persada et. al., 2019), dan hutan lindung Kota Langsa, kawasan tersebut menjadi destinasi wisata kota Langsa saat ini (Ramadani dan Navia, 2019).

Kota Langsa yang berada di Kawasan pesisir pantai timur Aceh menyimpan keanekaragaman hayati yang belum dieksplorasi semua. Sumber daya alam dari jenis bambu diketahui memiliki keanekaragaman yang cukup melimpah, namun masih banyak jenis bambu yang belum dikenal oleh masyarakat sehingga penelusuran ragam jenis bambu di suatu kawasan perlu dilakukan (Cahyanto, et. al. 2016). Diharapkan dari hasil penelitian ini dapat memberikan data dan informasi tentang bambu di Kota Langsa. Sehingga dapat dijadikan sebagai dasar bagi penyusun rencana dalam upaya perlindungan dan pelestarian yang akan dilakukan di masa mendatang.

\section{Metode Penelitian}

Penelitian telah dilakukan pada bulan April hingga Juli 2019. Lokasi penelitian di lima kecamatan yaitu di Kec. Langsa Kota, Langsa Barat, Langsa Baro, Langsa Timur, dan Langsa Lama, Kota Langsa, Aceh. Setiap kecamatan diambil satu desa secara purposive sampling (Navia, et. al. 2017; Njurumana 2016). Pengambilan sampel bambu di lapangan dengan metode eksplorasi (Rugayah, et. al. 2004). Pengamatan morfologi bambu berupa rumpun bambu, buku-buku bambu, pelepah buluh, daun pelepah daun, bentuk percabangan, dan rembung (Cahyanto et. al. 2016). Identifikasi jenis bambu yang mengacu pada Widjaja (2001a) dan Widjaja (2001b).

\section{Hasil Penelitian dan Pembahasan}

\section{Persebaran dan Ragam Jenis Bambu di Kota Langsa}

Berdasarkan hasil inventarisasi dan identifikasi bambu di lima Kecamatan yaitu Kecamatan Langsa Timur, Langsa Lama, Langsa Kota, Langsa Barat, dan Langsa Baro Kota Langsa diperoleh sebanyak 6 jenis bambu dan 4 marga. Adapun jenis-jenis bambu yang ditemukan dapat dilihat pada Tabel 1.

Hasil penelusuran bambu di Kota Langsa diperoleh 6 jenis yang tersebar di 5 kecamatan. Jenis bambu yang di temukan di Kota Langsa terbilang lebih sedikit jika dibandingkan dengan penelitian terdahulu di Kecamatan Tenggulun Kabupaten Aceh Tamiang sebanyak 8 jenis (Ritonga et. al., 2020). Bambu di Kota Langsa dijumpai sebanyak 2 jenis yang merupakan jenis introduksi dari luar kawasan Indonesia yaitu Thyrsostachys siamensis Gamble yang berasal dari Thailand dan Bambusa multiplex (Lour.) Raeusch. Ex Schhult., sedangkan jenis lainnya berasal dari Indonesia, yaitu Bambusa vulgaris Schrad. Ex Wendl., Gigantochloa apus (J.A. \& J.H.Schult.) Kurz, Gigantochloa atter (Hassk.) Kurz, dan Schizostachyum brachycladum.

Bambu G. apus persebarannya di Kec. Langsa Lama dan tumbuh di area kampus. Bambu S. brachycladum persebarannya di Kec. Langsa Kota dan Kec. Langsa Baro tumbuh di Hutan Lindung Kota Langsa, di pinggiran parit dan dijadikan sebagai tanaman hias. Bambu $B$. multiplex persebarannya di Kec. Langsa Lama, Langsa Kota, dan Langsa Baro tumbuh di sekitar pemukiman warga, pinggiran jalan, dan dijadikan sebagai pagar. Bambu T. siamensis persebarannya di Kec. Langsa Lama, Langsa Barat, dan Langsa Baro, tumbuh di sekitar pemukiman warga, area kampus Universitas Samudra, dan pinggiran jalan. Bambu B. vulgaris dan G. atter persebarannya di Kec. Langsa Timur, Langsa Lama, Langsa Barat, dan Langsa Baro, tumbuh mengikuti aliran sungai, pemukian warga, persawahan, serta dijadikan sebagai pagar dan tanaman hias.

Tabel 1 menunjukkan bahwa terdapat dua kecamatan memiliki jumlah jenis bambu terbanyak yaitu di Kec. Langsa Lama dan Langsa Baro sebanyak lima jenis. Jika ditinjau dari kondisi wilayah sangat sesuai, karena kedua kecamatan tersebut merupakan kawasan yang masih memiliki banyak perkebunan masyarakat seperti di Kec. Langsa Lama dan kawasan Hutan Lindung Kota Langsa di Kec. Langsa Baro. Sebagian besar masyarakatnya juga beraktivitas di perkebunan seperti karet dan sawit, serta juga bercocok tanam. Hal ini senada dengan penelitian Navia et. al. (2017) yang mengemukakan bahwa kedua lokasi tersebut memiliki tingkat keragaman yang tinggi dalam hal tanaman buah pekarangan. Jika ditinjau dari segi jumlah jenis bambu yang ditemukan di Kota Langsa (6 jenis) lebih banyak dari penelitian Ridwansyah et. al. (2015) di Hutan Kota Sanggau (3 jenis), Hadjar et. al. (2017) di Tahura Nipa-nipa (5 jenis), namun sama dengan di Desa Lopait Semarang (6 jenis) (Putro et. al. 2014). 
Penelusuran bambu di Kota Langsa ini menunjukkan bahwa tanaman bambu ini sebagian besar masih dimanfaatkan secara tradisional seperti penahan erosi di pinggir sungai dan parit, pagar rumah atau kebun, dan tanaman pinggir jalan maupun sebagai tanaman hias. Hingga saat ini bambu-bambu tersebut masih belum banyak diolah menjadi berbagai macam produk kerajinan. Padahal bambu memiliki potensi yang besar untuk diolah menjadi berbagai macam produk dalam kehidupan sehari-hari hingga skala industri, seperti di Desa Lopait Semarang (Putro et. al. 2014). Di desa ini masyarakatnya telah memanfaatkan bambu menjadi berbagai macam produk dengan 7 kategori, di antaranya adalah kerajinan dan bahan bangunan.

\section{Deskripsi Jenis Bambu di Kota Langsa}

Bambusa multiplex (Lour.) Raeusch. ex J.A. \& J.H.Schult.

Syst. Veg. 7: 1350 (1830) (Gambar 1).

Rumpun simpodial, tegak, dan rapat. Rebung hijau, diselimuti lilin putih. Buluh tinggi 2$7 \mathrm{~m}$, diameter $1,4 \mathrm{~cm}$, ruas $16-40 \mathrm{~cm}$, tegak dengan ujung melegkung. Percabangan terdiri atas satu cabang yang paling besar dikelilingi oleh beberapa cabang yang lebih kecil. Pelepah buluh mudah luruh dan gundul, 10,5-14,5 × 3-4 cm; kuping pelepah buluh seperti bingkai, mencapai 1-2 mm, dengan bulu kejur $2 \mathrm{~mm}$; ligula menggerigi, tinggi mencapai $1 \mathrm{~mm}$, gundul; daun pelepah tegak, menyegitiga dengan pangkal melebar, 9-12 × 44,5. Daun 6-10,5 × 0,5-1,3 cm; kuping kecil, mencapai $1 \mathrm{~mm}$, dengan bulu kejur pendek $1 \mathrm{~mm}$; ligula menggerigi, mencapai $1 \mathrm{~mm}$, gundul. Perbungaan tidak tersedia.

Habitat: Ditanam di pinggir jalan utama dan
Rumpun simpodial, tegak, dan tidak rapat. Rebung hijau dan kuning, tertutup miang cokelat kehitaman. Buluh agak berbiku-biku, tinggi 14-21 $\mathrm{m}$, diameter 6-7 cm, ruas 23-30 cm, tegak. Percabangan terdiri atas satu cabang yang paling besar dikelilingi oleh beberapa cabang yang lebih kecil. Pelepah buluh mudah luruh, diselimuti miang berwarna cokelat hingga hitam, 16-27 × 22$29 \mathrm{~cm}$; kuping membundar dan melengkung keluar, mencapai 11-14 mm, dengan bulu kejur 4$9 \mathrm{~mm}$; ligula menggerigi, tinggi 1-2 mm, bulu kejur pendek, 1-2 mm; daun pelepah segitiga dengan pangkal melebar, 7-21 × 7-10 cm, tegak. Daun 1730,5 × 2,5-5 cm; kuping kecil, mencapai $1 \mathrm{~mm}$, dengan bulu kejur 1-2 mm; ligula rata, mencapai 1 $\mathrm{mm}$, gundul. Perbungaan tidak tersedia.

Habitat: Ditanam pemukiman warga dan tumbuh di pinggir sungai.

Persebaran: Ditanam hampir di semua kota di Pulau Jawa (Widjaja, 2001b) dan Kepulauan Sunda Kecil (2001a).

Catatan: Jenis B. vulgaris mememiliki 3 varietas, yaitu $B$. vulgaris var. striata (buluh berwarna kuning bergaris hijau), B. vulgaris var. vulgaris (buluh berwarna hijau mengkilap), B. vulgaris var. wamin (buluh berwarna hijau menggelembung) (Widjaja, 2001b). Dalam penelitian ini hanya ditemukan 2 varietas, yaitu $B$. vulgaris var. striata dan $B$. vulgaris var. vulgaris.

Gigantochloa apus (J.A. \& J.H.Schult.f.) Kurz Natuurk. Tijdschr. Ned.-Indië 27: 226 (1864) (Gambar 4).

Rumpun simpodial, tegak, dan rapat. Rebung tidak dijumpai namun biasanya berwarna

Tabel 1. Ragam Jenis Bambu di Kota Langsa

\begin{tabular}{|c|c|c|c|c|c|c|}
\hline \multirow[t]{2}{*}{ No. } & \multirow[t]{2}{*}{ Marga/Jenis } & \multicolumn{5}{|c|}{ Lokasi } \\
\hline & & LT & LL & LK & LBa & LBr \\
\hline & Bambusa Schreb. & & & & & \\
\hline 1 & Bambusa multiplex (Lour.) Raeusch. Ex Schhult. & & $\mathbf{X}$ & $\mathbf{X}$ & & $\mathbf{X}$ \\
\hline 2 & $\begin{array}{l}\text { Bambusa vulgaris Schrad. Ex Wendl. } \\
\text { Gigantochloa Kurz ex Munro }\end{array}$ & $\mathbf{X}$ & $\mathbf{X}$ & $\mathbf{X}$ & $\mathbf{X}$ & $\mathbf{X}$ \\
\hline 3 & Gigantochloa apus (J.A. \& J.H.Schult.) Kurz & & $\mathbf{X}$ & & & \\
\hline 4 & $\begin{array}{l}\text { Gigantochloa atter (Hassk.) Kurz } \\
\text { SchizostachyumNees }\end{array}$ & $\mathbf{X}$ & $\mathbf{X}$ & & $\mathbf{X}$ & $\mathbf{X}$ \\
\hline 5 & $\begin{array}{l}\text { Schizostachyumbrachycladum (Kurz) Kurz } \\
\text { ThyrsostachysGamble }\end{array}$ & & & $\mathbf{X}$ & & $\mathbf{X}$ \\
\hline 6 & Thyrsostachys siamensis Gamble & & $\mathbf{X}$ & & $\mathbf{X}$ & $\mathbf{X}$ \\
\hline
\end{tabular}

Keterangan: LT: Langsa Timur; LL: Langsa Lama; LK: Langsa Kota; LB: Langsa Barat; LBr: Langsa Baro

pemukiman warga.

Persebaran: Diintroduksi di seluruh Pulau Jawa terutama di kota-kota besar (Widjaja, 2001b). Bambusa vulgaris Schrad ex wendl.

Coll. Pl. 2: 26 (1808) (Gambar 2 dan 3). hijau tertutup miang hitam dan cokelat (Widjaja, 2001b). Buluh tinggi 13-26 m, diameter 5,5-6,5 $\mathrm{cm}$, ruas $40-48 \mathrm{~cm}$, tegak. Percabangan terdiri atas satu cabang yang paling besar dikelilingi oleh beberapa cabang yang lebih kecil. Pelepah buluh 
tidak mudah luruh, diselimuti miang berwarna hitam, 24,5-25 × 17-19 cm; kuping membingkai, mencapai 1-2 mm, dengan bulu kejur 1-3 mm; ligula menggerigi, tinggi 1-3 mm, gundul; daun pelepah menyegitiga dengan pangkal meyempit, 2,5-8 × 1-3 cm, terkeluk balik. Daun 29-32,5 × 5$5,5 \mathrm{~cm}$; kuping kecil, mencapai 1-2 mm, gundul; ligula rata, mencapai 2-3 mm, gundul. Perbungaan tidak tersedia.

Habitat: Tumbuh di area kampus Universitas Samudra (UNSAM).

Persebaran: Ditanam di seluruh Jawa dan tumbuh liar (Widjaja, 2001b).

Gigantochloa atter (Hassk.) Kurz

Natuurk. Tijdschr. Ned.-Indië 27: 226 (1864) (Gambar 5).

Rumpun simpodial, tegak, dan rapat. Rebung hijau hingga keunguan, tertutup miang hitam hingga cokelat. Buluh tinggi 4-21 m, diameter 5-9,5 cm, ruas 21-48 cm, tegak. Percabangan terdiri atas satu cabang yang paling besar dikelilingi oleh beberapa cabang yang lebih kecil. Pelepah buluh mudah luruh, diselimuti miang berwarna hitam, 35-37 × 26-31,5 cm; kuping membundar ujung melengkung keluar, mencapai 2-7 mm, dengan bulu kejur yang pendek; ligula menggerigi, tinggi mencapai 1-3 $\mathrm{mm}$, gundul; daun pelepah menyegitiga dengan pangkal meyempit, 7,5- 8,5 × 1,5-2 cm, terkeluk balik. Daun 30-33,5 × 3-5 cm; kuping kecil, mencapai $2 \mathrm{~mm}$, gundul; ligula rata, mencapai 2 $\mathrm{mm}$, gundul. Perbungaan tidak tersedia.

Habitat: Ditanam di pinggir sungai dan pemukiman warga.

Persebaran: Tumbuh tersebar di Jawa dan juga daerah lain di Indonesia (Widjaja, 2001b).

Schizostachyum brachycladum (Kurz) Kurz

J. Asiat. Soc. Bengal, Pt. 2, Nat. Hist. 39: 89 (1870) (Gambar 6).

Rumpun simpodial, tegak, dan rapat. Rebung hijau kekuningan, tertutup miang cokelat gelap. Buluh tinggi 4-11 m, diameter 4,5-5 cm, ruas 30,5-40 cm, tegak. Percabangan sama besar. Pelepah buluh tidak mudah luruh, diselimuti miang berwarna cokelat, 10,5 × 23,5 cm; kuping kecil, mencapai 2-4 mm, dengan bulu kejur yang lebih dari $4 \mathrm{~mm}$; ligula rata, lebih dari $1 \mathrm{~mm}$, gundul; daun pelepah segitiga, 7,5- 8,5 × 4,5-5,5 $\mathrm{cm}$, tegak. Daun 12,5-31,5 × 4-5-6,5 cm; bagian bawah terdapat bulu balig; kuping kecil, mencapai $1 \mathrm{~mm}$ dengan bulu kejur 10-14mm; ligula rata, mencapai $1 \mathrm{~mm}$, gundul. Perbungaan $15-28 \mathrm{~cm}$ panjangnya, spikelet $1-2 \mathrm{~cm}$.

Habitat: Ditanam di pinggir parit.
Persebaran: Di Jawa varietas hijau hanya dapat di beberapa tempat, sedangkan yang kuning ditanam hampir di setiap kota (Widjaja, 2001b).

Catatan: Jenis $S$. brachycladum mememiliki 2 varietas, yaitu buluh berwarna kuning dan buluh berwarna hijau.

\section{Thyrsostachys siamensis Gamble}

Ann. Roy. Bot. Gard. (Calcutta) 7: 59 (1896) (Gambar 7).

Rumpun simpodial, tegak, dan padat. Rebung hijau pudar sampai keunguan, gundul tidak bermiang. Buluh tingginya mencapai $7 \mathrm{~m}$, diameter 3-4 cm, ruas 7-29 cm, tegak. Percabangan terdiri atas satu cabang yang paling besar dikelilingi oleh beberapa cabang yang lebih kecil. Pelepah buluh tidak mudah luruh, tertutup bulu putih, $36-38 \times 29-30,5 \mathrm{~cm}$; kuping pelepah buluh tidak terlihat, gundul; ligula rata, tinggi 1 $\mathrm{mm}$, gundul; daun pelepah buluh tegak dan mullah luruh. Daun 7,5-15 × 0,6-0,8 cm, gundul, keputihputihan; kuping pelepah buluh tidak terlihat, gundul; ligula rata, tinggi kurang dari $1 \mathrm{~mm}$, gundul.

Habitat: Ditanam di perkebunan kelapa sawit, pinggri sungai, pemukiman warga.

Persebaran: Tumbuh tersebar dan terutama di kota-kota besar, sedangkan di Jawa sudah ditanam sampai ke pelosok-pelosok desa (Widjaja, 2001b).

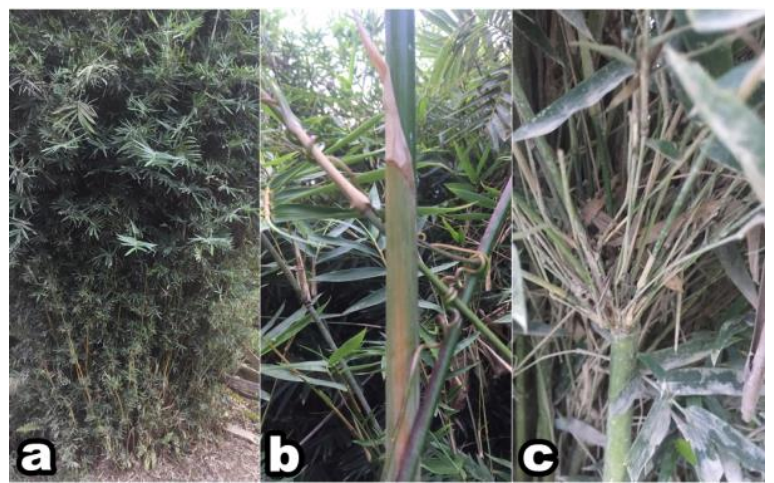

Gambar 1. Bambusa multiplex (Lour.) Raeusch. ex J.A. \& J.H.Schult.

Keterangan: (a) Rumpun, (b) Pelepah Buluh, dan (c) Percabangan

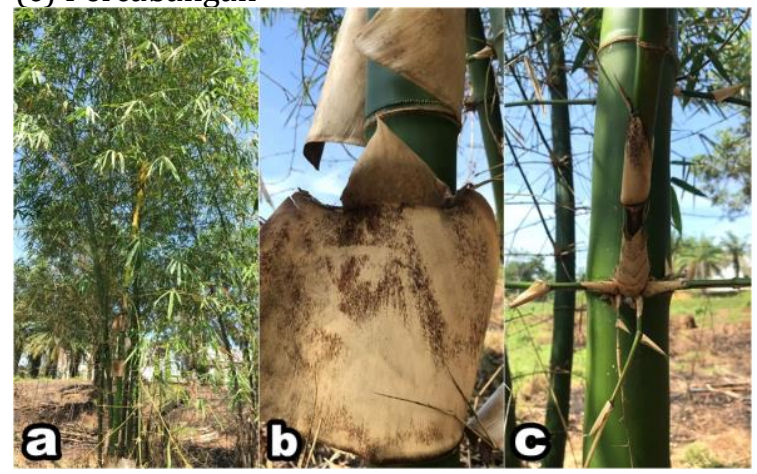

Gambar 2.Bambusa vulgaris var. vulgaris 
Keterangan: (a) Rumpun, (b) Pelepah Buluh, dan (c) Percabangan

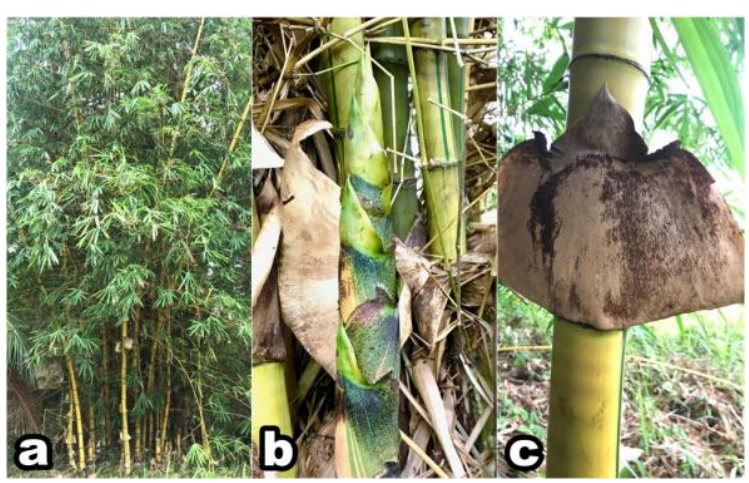

Gambar 3. B. vulgaris var. striata

Keterangan: (a) Rumpun, (b) Rebung, dan (c)

Pelepah Buluh

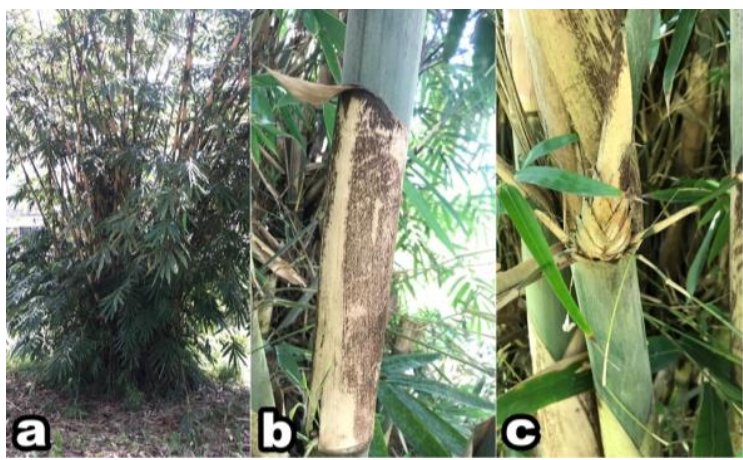

Gambar 4. Gigantochloa apus (J.A. \& J.H.Schult.f.) Kurz

Keterangan: (a) Rumpun, (b) Pelepah Buluh, dan (c) Percabangan

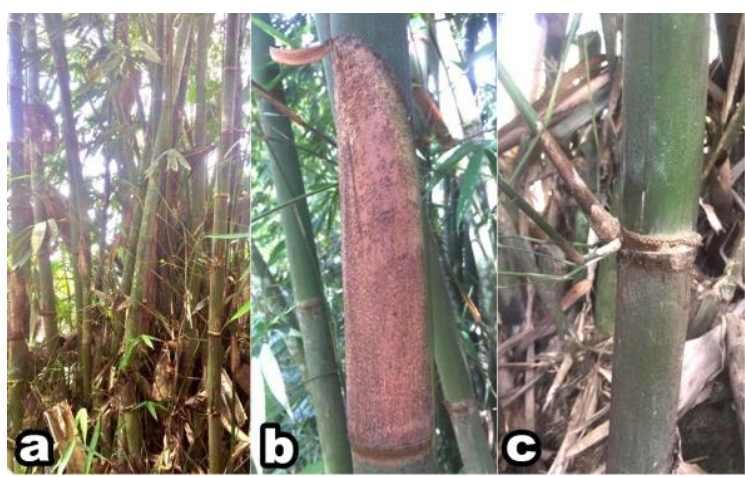

Gambar 5. Gigantochloa atter (Hassk.) Kurz

Keterangan: (a) Rumpun, (b) Pelepah Buluh, dan (c) Percabangan

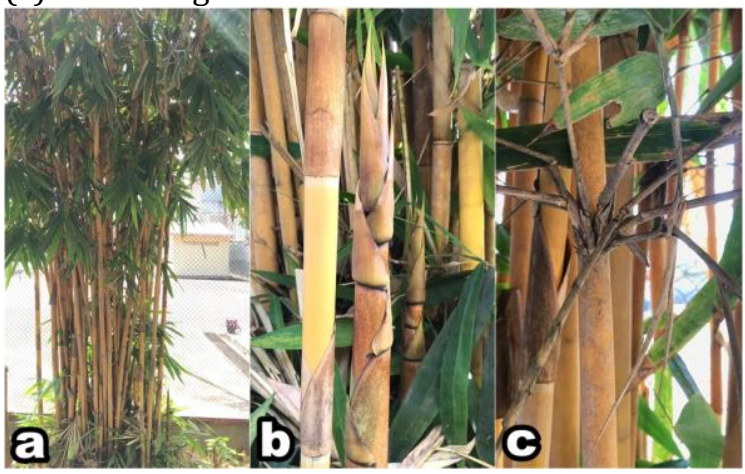

Gambar 6. Schizostachyum brachycladum (Kurz) Kurz

Keterangan: (a) Rumpun, (b) Rebung, dan (c)

Percabangan

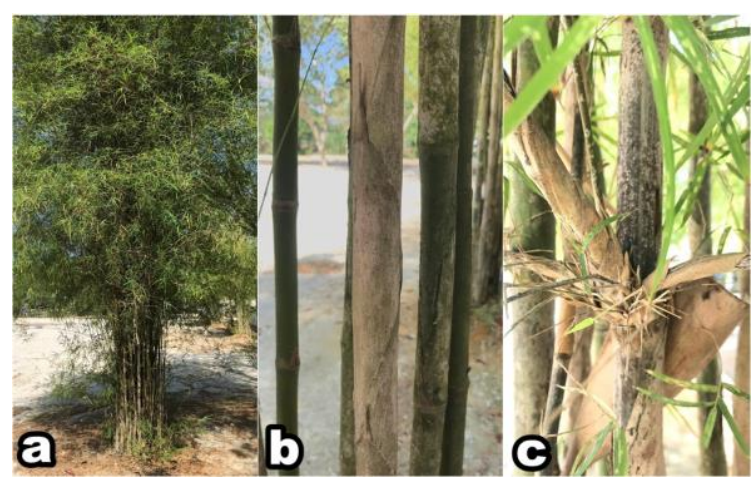

Gambar 7. Thyrsostachys siamensis Gamble

Keterangan: (a) Rumpun, (b) Pelepah Buluh, dan (c) Percabangan

\section{Simpulan}

Ragam jenis bambu yang dijumpai di Kota Langsa ditemukan sebanyak 4 marga terdiri atas 6 jenis, yaitu B. multiplex, B. vulgaris, G. apus, G. atter, S.brachycladum, dan $T$. siamensis. Persebaran bambu di Kota Langsa paling banyak dijumpai di Kec. Langsa Lama dan Langsa Baro berjumlah 5 jenis.

\section{Daftar Pustaka}

Afriani, R., Manik, H., Saputri, S., Mandasari, O., Navia, Z. I. 2019. Keragaman jenis jamur makroskopis pada perkebunan masyarakat kampung Lengkong, Kota Langsa. Dalam: Suwardi, A. B. Seprianto, Hasby, Sari, R. P., Fadlia, Mustika, D. (editor) Prosiding Seminar Nasional Peningkatan Mutu Pendidikan yang diselengarakan oleh Fakultas Keguruan dan Ilmu Pendidikan, 1(1): 265 - 269.

Cahyanto, T., Ariustin, D., Efendi, M. 2016. Keanekaragaman jenis bambu di Gunung Ciremai Jawa Barat. Biogenesis. 4(2): 90-94.

Garuda, Pelawi, L. H. Br., Nadilla, F., Rosanti, E., Navia, Z. I. 2019. Keragaman jenis jamur makroskopis di kecamatan Langsa Lama, Langsa, Aceh. Dalam: Suwardi, A. B. Seprianto, Hasby, Sari, R. P., Fadlia, Mustika, D. (editor) Prosiding Seminar Nasional Peningkatan Mutu Pendidikan yang diselengarakan oleh Fakultas Keguruan dan Ilmu Pendidikan, 1(1): 175 - 179.

Hadjar, N., Pujirahayu, N., Fitriono, E. 2017. Keragaman jenis bambu (Bambusa sp.) di 
Kawasan Tahura Nipa-Nipa Kelurahan Mangga Dua. Ecogreen. 3(1): 9-16.

Navia, Z. I., Suwardi, A. B., Saputri, A. 2017. Penelusuran ragam jenis tanaman buah pekarangan sebagai sumber nutrisi bagi masyarakat di kota langsa, ACEH. Dalam: Agustien, A., Syaifullah, Pitopang, RP, Nurainas, Ilyas, S. \& Kurniawan, R. (editor) Prosiding Seminar Nasional Biodiversitas dan Ekologi Tropika Indonesia Ke-4 dan Kongres Penggalang Taksonomi Tumbuhan Indonesia Ke-12 yang diselengarakan oleh Jurusan Biologi FMIPA Unand, tanggal 15-17 September 2017. Padang: Universitas Andalas.

Navia, Z. I., Suwardi, A. B., Saputri, A. 2019. Karakterisasi tanaman buah lokal di Kawasan Ekosistem Leuser Kabupaten Aceh Tamiang, Aceh. Buletin Plasma Nutfah. 25(2): 57-66.

Navia, Z.I., Suwardi, A. B., Harmawan, T, Syamsuardi, Mukhtar, E. 2020. The diversity and contribution of indigenous edible fruit plants to the rural community in the Gayo Highlands, Indonesia. Journal of Agriculture and Rural Development in the Tropics and Subtropics, 121(1): 89-98.

Njurumana G. N. 2016. Masyarakat desa dan manajemen biodiversitas flora pada sistem pekarangan di Kabupaten Sumba Tengah. Jurnal Penelitian Kehutanan Wallacea. 5(1): 25-36.

Persada, A. Y., Navia, Z. I., Saputri, A., Putri, K. A., Fajar, B. A. 2019. Inventaris jenis fitoplankton di Pulau Pusong, Langsa, Aceh. Elkawnie. 5(1): 67-75.

Putro, D. S., Jumari, Murningsih. 2014. Keanekaragaman jenis dan pemanfaatan bambu di Desa Lopait Kabupaten Semarang Jawa Tengah. Jurnal Biologi. 3(2): 71-79.

Ramadani, R dan Navia, Z. I. 2019. Pengembangan Potensi Ekowisata Hutan Mangrove Di Desa Kuala Langsa Kecamatan Langsa Barat Kota Langsa Aceh. Jurnal Biologica Samudra.1(1): 41-55.

Ridwansyah, Husni, H., Wulandari, R. S. 2015. Keanekaragaman jenis bambu di Hutan Kota KelurahanBunut Kabupaten Sanggau. Jurnal Hutan Lestari. 3 (2): 199-207.
Ritonga, M. A., Navia, Z. I., Arico, Z. 2020. Pemanfaatan bambu oleh masyarakat di Kecamatan Tenggulun, Kabupaten Aceh Tamiang. Jurnal Biologica Samudra. 2 (1): 10-19.

Rugayah, A. Retnowati, F.I. Windadri, A. Hidayat, 2004. Pengumpulan Data Taksonomi. Dalam: Rugayah, E.A. Widjaja, dan Praptiwi (editor). Pedoman Pengumpulan Data Keanekaragaman Flora. Bogor: Pusat Penelitian Biologi-LIPI.

Saputri, A. \& Navia, Z. I. 2017. Keanekaragaman jenis tanaman ekonomis berfungsi ekologis di kawasan ekosistem leuser Kabupaten Aceh Tamiang. Dalam: Agustien, A., Syaifullah, Pitopang, RP, Nurainas, Ilyas, S. \& Kurniawan, R. (editor) Prosiding Seminar Nasional Biodiversitas dan Ekologi Tropika Indonesia Ke-4 dan Kongres Penggalang Taksonomi Tumbuhan Indonesia Ke-12 yang diselengarakan oleh Jurusan Biologi FMIPA Unand, tanggal 15-17 September 2017. Padang: Universitas Andalas.

Saputri, A. Amna, U., Navia, Z. I. 2018. Skrining fitokimia buah rumbia (Metroxylon sagu Rottb): studi pendahuluan pengembangan obat herbal anti hipertensi. Dalam: Syahril, M., Haser, T. F., Heviyanti, M., Alham, F., Siregar, D. S., \& Abdurachman (editor) Seminar Nasional Pertanian dan Perikanan yang diselengarakan oleh Fakultas Pertanian Unsam, tanggal 5-6 September 2018. Langsa: Universitas Samudra.

Sukma, M. O. dan Lianah. 2019. Inventarisasi tanaman bambu di Balai Kebun Raya Baturraden Banyumas Jawa Tengah, AlHayat: Journal of Biology and Applied Biology. 2(2): 59-64.

Sulistiono, Karyningsih, I., Nugraha, A. 2016. Keanekaragaman jenis bambu dan pemanfaatannya di kawasan hutan Gunung Tilu Desa Jabranti Kecamatan Karangkencana Kabupaten Kuningan. Wanakarsa. 10(2): 41-47.

Suwardi, A. B., Sofiyan, Navia, Z. I. 2017. Komposisi jenis dan cadangan karbon tersimpan di hutan mangrove Kuala Langsa, Aceh. Dalam: Agustien, A., Syaifullah, Pitopang, RP, Nurainas, Ilyas, S. \& Kurniawan, R. (editor) Prosiding Seminar Nasional Biodiversitas dan Ekologi Tropika Indonesia Ke-4 dan Kongres Penggalang Taksonomi Tumbuhan Indonesia Ke-12 yang 
diselengarakan oleh Jurusan Biologi FMIPA Unand, tanggal 15-17 September 2017. Padang: Universitas Andalas.

Suwardi, A. B., Indriaty, \& Navia, Z. I. 2018. Nutritional evaluation of some wild edible tuberous plants as an alternative foods. Innovare Journal of Food Science. 6 (2): 912.

Suwardi, A. B., Navia, Z.I., Harmawan, T, Syamsuardi, Mukhtar, E. 2019a. Sensory Evaluation of Mangoes Grown in Aceh Tamiang District, Aceh, Indonesia. Advances in Ecological and Environmental Research, 4(3): 79-85.

Suwardi, A. B., Navia, Z. I., Harmawan, T., Syamsuardi, \& Mukhtar, E. 2019b. The diversity of wild edible fruit plants and traditional knowledge in West Aceh region, Indonesia. Journal of Medicinal Plants Studies. 7(4): 285-290.

Suwardi, A. B., Navia, Z.I., Harmawan, T, Syamsuardi, Mukhtar, E. 2020a. Ethnobotany, nutritional composition and sensory evaluation of Garcinia from Aceh, Indonesia. IOP Conference Series: Materials Science and Engineering. 725(1): 012-064.

Suwardi, A. B., Navia, Z. I., Harmawan, T., Syamsuardi, Mukhtar, E. 2020b. Ethnobotany and conservation of indigenous edible fruit plants in South Aceh, Indonesia. BIODIVERSITAS. 21(5): 1850-1860.

Widjaja, E.A. 2001a. Identikit Jenis-jenis Bambu di Kepulauan Sunda Kecil. Bogor: Herbarium Bogoriense, Balitbang Botani, Puslitbang Biologi-LIPI.

Widjaja, E.A. 2001b. Identikit Jenis-jenis Bambu di Jawa. Bogor: Pusat Penelitian Biologi-LIPI.

Zulkarnaen, R. N., dan Andila, P. S. 2015. Dendrocalamus spp: Bambu raksasa koleksi Kebun Raya Bogor. Prosiding Seminar Nasional Masyarakat Biodiversitas Indonesia yang diselengarakan oleh Masyarakat Biodiversitas Indonesia, tanggal 21 Maret 2015. Yogyakarta: Masyarakat Biodiversitas Indonesia. 